\title{
Ecological particularities of the critically endangered killifish Valencia letourneuxi and its spring-fed habitats: a long-lost endemic species of south Albania ${ }^{\star}$
}

\author{
Spase Shumka ${ }^{1, *}$, Eleni Kalogianni ${ }^{2}$, Radek Šanda ${ }^{3}$, Jasna Vukić ${ }^{4}$, Laura Shumka ${ }^{5}$ \\ and Brian Zimmerman ${ }^{6}$ \\ ${ }^{1}$ Department of Biotechnology and Food, Faculty of Biotechnology and Food, Agricultural University of Tirana, Tirana, Albania \\ ${ }^{2}$ Hellenic Centre for Marine Research, Institute of Marine Biological Resources and Inland Waters, 19013 Anavyssos, Greece \\ ${ }^{3}$ Department of Zoology, National Museum, Václavskénám. 68, 11000 Prague 1, Czech Republic \\ ${ }^{4}$ Department of Ecology, Faculty of Science, Charles University, Viničná 7, 12844 Prague 2, Czech Republic \\ ${ }^{5}$ Department of Architecture, Faculty of Architecture and Applied Economics, Albanian University, Tirana, Albania \\ ${ }^{6}$ Zoological Society of London, Regent's Park, London NW1 4RY, UK
}

Received: 26 July 2020 / Accepted: 2 November 2020

\begin{abstract}
The southernmost part of Albania, the Butrinti Lake area is characterised by a highly diverse freshwater fish community with a high degree of regional endemism. This study focuses on the Corfu killifish (or toothcarp) Valencia letourneuxi (Sauvage, 1880) that is endemic to the western part of the Ionian Ecoregion, and reported in Albania in the past from a single location, Lake Butrinti. Recently, in June 2019, the species has been rediscovered at a very low population density (only 11 individuals collected) in a spring-fed stream in the vicinity of Lake Butrinti. Other fish present together with $V$. letourneuxi were the native Telestes pleurobipunctatus, Barbus peloponnesius, Anguilla anguilla and Pelasgus thesproticus and the translocated Alburnus sp. Our findings provide useful insights into the ecology and conservation of a Critically Endangered, range-restricted species and its habitats. The Corfu killifish presence correlated negatively with water depth and positively with aquatic vegetation coverage. The conservation implications of our findings both for the target species and the co-occurring fish fauna in its spring-fed habitats are discussed.
\end{abstract}

Keywords: Valencia letourneuxi / Lake Butrinti / conservation / priority species / Critically Endangered

\begin{abstract}
Résumé - Particularités écologiques de Valencia letourneuxi, gravement menacé, et de ses habitats alimentés par des sources: une espèce endémique du sud de l'Albanie, disparue depuis longtemps. La partie la plus méridionale de l'Albanie, la région du lac Butrinti, se caractérise par une communauté de poissons d'eau douce très diversifiée, avec un degré élevé d'endémisme régional. Cette étude se concentre sur le fondule de Corfou Valencia letourneuxi (Sauvage, 1880) qui est endémique à la partie occidentale de l'écorégion ionienne, et qui était autrefois signalé en Albanie à partir d'un seul endroit, le lac de Butrinti. Récemment, en juin 2019, l'espèce a été redécouverte à une très faible densité de population (seulement 11 individus collectés) dans un ruisseau alimenté par une source, à proximité du lac Butrinti. Les autres poissons présents avec $V$. letourneuxi étaient les espèces indigènes Telestes pleurobipunctatus, Barbus peloponnesius, Anguilla anguilla, Pelasgus thesproticus et l'Alburnus sp. Nos résultats fournissent des informations utiles sur l'écologie et la conservation d'une espèce en danger critique d'extinction et dont l'aire de répartition est limitée, ainsi que sur ses habitats. La présence du fondule de Corfou est corrélée négativement à la profondeur de l'eau et positivement à la couverture de végétation aquatique. Les implications de nos conclusions en matière de conservation, tant pour l'espèce cible que pour la faune piscicole co-occurrente dans ses habitats alimentés par une source, sont discutées.
\end{abstract}

Mots clés : Valencia letourneuxi / lac Butrinti / conservation / espèces prioritaires / en danger critique d'extinction

\footnotetext{
$\star$ The affiliations of the co-authors Radek Šanda and Jasna Vukić have been corrected.

*Corresponding author: sprespa@gmail.com
} 


\section{Introduction}

The Mediterranean region has long been recognised as a globally important biodiversity hotspot (Myers et al., 2000; Geiger et al., 2014) with the Lake Butrinti area listed among the key biodiversity areas of the Mediterranean (Darwall et al., 2014), as well as a National Park, RAMSAR site and UNESCO site, due to the conservation status and the high local species endemicity. Currently the main threats to the freshwater ecosystems of Albania (and the Lake Butrinti ecosystem) are hydropower development, water abstraction for agro-industry, land use changes in the upper parts of the associated catchments, and tourism in the coastal areas (Shumka, 2019). Invasive species in the watershed also present a significant threat to the native fauna (Shumka, 2019). The Lake Butrinti ecosystem hosts a unique freshwater ichthyofauna comprising numerous endemic species with restricted distribution (Crivelli and Maitland, 1995), with more than half of these species currently considered to be threatened (Darwall et al., 2014).

The Family Valenciidae is the only fish family endemic to Europe, inhabiting the Mediterranean basin (Freyhof et al., 2014). Valencia is the only genus in the Valenciidae family (Myers, 1928; Parenti, 1981; Bianco and Miller 1989; Seegers 1980; Vilwock et al. 1982; Woeltjes 1982; Woeltjes 1988), with three species known, i.e. the Valencia toothcarp $V$. hispanica (Valenciennes, 1846), described from Catalonia, Spain, with distribution in the Eastern Spanish coastline (Oliva et al., 2009; Oliva 1965), the Corfu toothcarp V. Letourneuxi (Sauvage, 1880) described from Corfu Island, Greece, with distribution in north-western Greece and southern Albania, and its sister species, the recently described Peloponnese toothcarp Valencia robertae Freyhof, Kärst \& Geige, 2014, that encompasses the most southern populations of the genus in Greece, previously considered as $V$. letourneuxi. Due to the very restricted distribution of $V$. letourneuxi and $V$. robertae the continuing deterioration of their habitats and the extinction or decline of extant populations (Kalogianni et al., 2010; Barbieri et al. 2002; Daoulas 2003; Dill 1993), V. letourneuxi the species has been included in the lists of the Bern Convention as an endangered and strictly protected species, and has been characterised as a priority species for conservation in Annex II of the European Union Habitats Directive 92/43/EEC. It was also classified as Critically Endangered by the IUCN, based on restricted distribution, suspected population decline and projected decline in the coming decade, as well as due to impacts of introduced alien species (Crivelli, 2006). The species is included in the Greek Red list of threatened species (Legakis and Maragou, 2009) but not on the Albanian Red list due to data deficiency. To ensure the conservation of the species, coordinated conservation initiatives in Greece and Albania are urgently required to mitigate the impacts of habitat degradation and of competition with the alien Eastern mosquitofish Gambusia holbrookiare (Barbieri et al., 2015; Kalogianni et al., 2019), including considerations of the establishment of NATURA 2000 sites in Albania (Shumka, 2019).
Data on freshwater fish assemblages provide a unique view into freshwater biota, establishing a much-needed baseline for monitoring freshwater ecosystem health and for the delineation of appropriate conservation measures. More specifically, according to Sutela et al. (2010), fish are not distributed randomly in riverine ecosystems but exhibit a spatially varying assemblage structure, influenced by habitat conditions and anthropogenic pressures. Furthermore, classifications of fish assemblages are critically important for biodiversity conservation, since individual fish assemblage or community units may warrant specific conservation actions (Angermeier and Winston, 2003). Fish assemblage classification is also dependent on accurate knowledge of fish taxonomy, which is an active research area in recent years, especially in globally important biodiversity areas, such as the Balkans (Kottelat and Freyhof, 2007).

This study focused on the River Pavllo catchment, Lake Butrint drainage, an isolated Mediterranean catchment in the Ionian Sea slope in southern Albania. It provides data on the current population status of a Critically Endangered, rangerestricted freshwater species in Albania. It also assesses various aspects of species' interactions and fish community assemblage, to help build baseline knowledge for future biodiversity and river conservation initiatives.

\section{Material and methods}

\subsection{Study area}

The study area is situated in southern Albania, at the borders with Greece. It includes the wider geographical area surrounding Butrinti Lake, where V. letourneuxi presence has been reported previously (Oliva, 1961). It includes Lakes Butrinti and Buffi, the River Pavllo and its tributaries, communication canals, and small spring-fed streams (Figs. 1 and 4, Tab. 1). Surveys were conducted during May-August 2019 in a total of eight locations in the basin.

\subsection{Data collection}

Field sampling was conducted using a D-shaped hand net and seine nets, depending on the density of aquatic vegetation. Water flow $(\mathrm{m} / \mathrm{s})$, substrate composition structure, depth $(\mathrm{m})$, width $(\mathrm{m})$ and vegetation cover $(\%)$ were recorded. Water physical-chemical parameters, i.e. conductivity $(\mu \mathrm{S} / \mathrm{cm})$, temperature $\left({ }^{\circ} \mathrm{C}\right), \mathrm{pH}$ and dissolved oxygen $(\mathrm{mg} / \mathrm{L})$ were recorded in situ with a Hanna multiparameter HI98194analyzer and the appropriate probes. Site habitat and physicalchemical parameters are presented in Tables 1 and 2. Fish caught were measured (standard length to the nearest $\mathrm{mm}$ ), weighed (to the nearest $0.001 \mathrm{~g}$ ) and then returned to the water. Methods for counts and measurements follow Kottelat and Freyhof (2007). Standard length (SL) is measured from the tip of the upper lip to the end of the hypural complex. Species identification and nomenclature follows Kottelat and Freyhof (2007) with modifications from Zupančič et al. (2010) and Marková et al. (2010). A small number of specimens were 


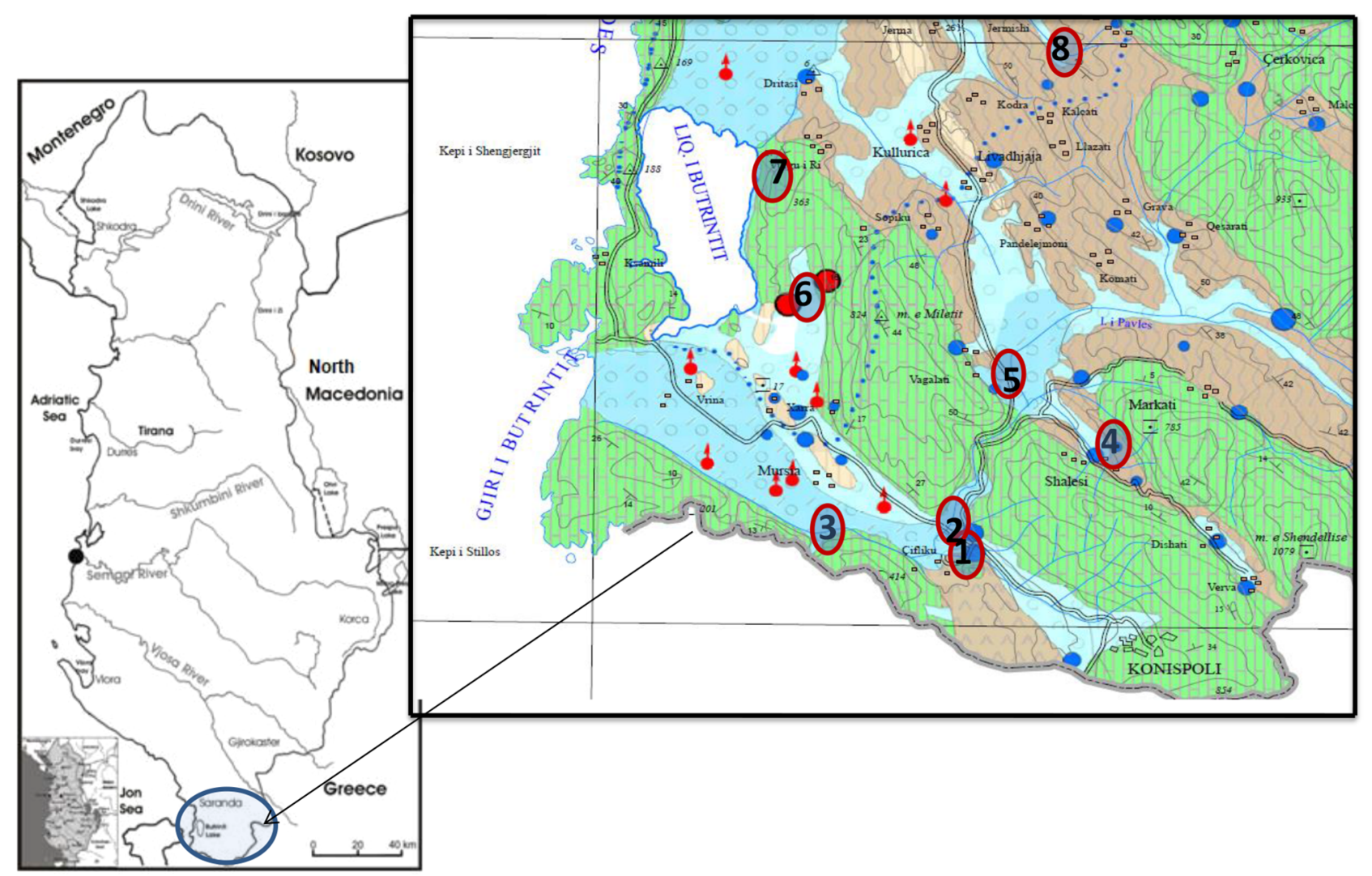

Fig. 1. Site location and sampling area (blue dots denote water springs, red dots denote aquifers).

Table 1. Data on sampling sites, water body type, substrate structure and $V$. letourneuxi presence $(\mathrm{P})$ or absence (A).

\begin{tabular}{lll}
\hline $\begin{array}{l}\text { Location } \\
\text { (WP-waypoints) }\end{array}$ & Water body type & $\begin{array}{l}\text { V. letourneuxi } \\
\text { presence }\end{array}$ \\
\hline$(1)$ & Spring-fed stream, freshwater & $\mathrm{P}$ \\
$(2)$ & Spring-fed stream, freshwater & $\mathrm{P}$ \\
$(3)$ & Spring-fedstream, freshwater & $\mathrm{P}$ \\
$(4)$ & Spring-fed stream, freshwater & $\mathrm{A}$ \\
$(5)$ & River, freshwater & $\mathrm{A}$ \\
$(6)$ & Spring-fed stream, brackish & $\mathrm{A}$ \\
$(7)$ & channel, freshwater & $\mathrm{P}$ \\
$(8)$ & River, freshwater & $\mathrm{A}$ \\
\hline
\end{tabular}

euthanised with cloveoil and deposited in ethanol in the Agricultural University of Tirana for future genetic analysis.

\subsection{Data analysis}

The "PAST" software was applied in data analyses. PCA analysis was conducted to elucidate associations between environmental variables and $V$. letourneuxi presence/absence data. Analysis of variance (ANOVA) was then applied to test for significant differences in vegetation cover, dissolved oxygen concentration, $\mathrm{pH}$, conductivity, flow, depth and water temperature among the various sites assessed for $V$. letourneuxi presence. Bray-Curtis similarity with group average linking (UPGMA tree) was used, to cluster the different sampling sites, according to their fish community, and to produce a similarity tree-plot. Next, Multi-Dimensional Scaling (MDS) ordination was used, in order to find the relative placement of the samples in a two-axis ordination plot, according to their fish fauna.

\section{Results and discussion}

\subsection{Distribution and abundance}

In the studied catchment area (approx. $400 \mathrm{~km}^{2}$ ), we recorded $V$. letourneuxi in a very limited part of the catchment, i.e. in a $900 \times 900 \mathrm{~m}\left(0.81 \mathrm{~km}^{2}\right)$ section of a small-sized, spring-fed stream basin (Locations, 1, 2 and 3, Fig. 1). Valencia letourneuxi was found mainly along the well-oxygenated channel of this stream, with high vegetation cover and low water velocity (Fig. 2). Our surveys of neighboring water bodies, including the main ditch of the River Pavllo and associated wetlands, revealed either very low $V$. letourneuxi densities or did not reveal the presence of the species there.

Valencia letourneuxi in Albania has been previously reported in Lake Butrinti, without however a specification of the exact locality (Oliva, 1961). Oliva (1961) also reported that 
Table 2. Sampling sites in the Lake Butrinti area, with total number of fish caught $(n)$, species caught and relative abundances.

\begin{tabular}{|c|c|c|c|}
\hline $\begin{array}{l}\text { Site } \\
\text { WP }\end{array}$ & $n$ & Species & $\begin{array}{l}\text { Relative } \\
\text { abundance (\%) }\end{array}$ \\
\hline \multirow[t]{6}{*}{ (1) } & \multirow[t]{6}{*}{143} & Pelasgusthesproticus & 53.85 \\
\hline & & Telestespleurobipunctatus & 11.19 \\
\hline & & Squaliuspamvoticus & 11.89 \\
\hline & & Barbuspeloponnesius & 9.09 \\
\hline & & Anguilla anguilla & 6.29 \\
\hline & & Valencia letourneuxi & 7.69 \\
\hline \multirow[t]{6}{*}{ (2) } & \multirow[t]{6}{*}{112} & Pelasgusthesproticus & 55.36 \\
\hline & & Telestespleurobipunctatus & 13.39 \\
\hline & & Squaliuspamvoticus & 11.61 \\
\hline & & Barbuspeloponnesius & 16.07 \\
\hline & & Anguilla anguilla & 0.89 \\
\hline & & Valencia letourneuxi & 2.68 \\
\hline \multirow[t]{6}{*}{ (3) } & \multirow[t]{6}{*}{79} & Pelasgusthesproticus & 70.89 \\
\hline & & Squaliuspamvoticus & 6.33 \\
\hline & & Barbuspeloponnesius & 11.39 \\
\hline & & Anguilla anguilla & 5.06 \\
\hline & & Alburnussp. & 3.8 \\
\hline & & Valencia letourneuxi & 2.53 \\
\hline \multirow[t]{5}{*}{ (4) } & \multirow[t]{5}{*}{66} & Pelasgusthesproticus & 64.58 \\
\hline & & Telestespleurobipunctatus & 4.17 \\
\hline & & Squaliuspamvoticus & 8.33 \\
\hline & & Barbuspeloponnesius & 8.33 \\
\hline & & Pachychilonpictum & 15.58 \\
\hline \multirow[t]{7}{*}{ (5) } & \multirow[t]{7}{*}{65} & Pelasgusthesproticus & 49.23 \\
\hline & & Telestespleurobipunctatus & 12.31 \\
\hline & & Squaliuspamvoticus & 10.77 \\
\hline & & Barbuspeloponnesius & 16.92 \\
\hline & & Salariafluviatilis & 4.62 \\
\hline & & Anguilla anguilla & 1.54 \\
\hline & & Pachychilonpictum & 4.62 \\
\hline \multirow[t]{3}{*}{ (6) } & \multirow[t]{3}{*}{14} & Mugilsp. & 21.43 \\
\hline & & Anguilla anguilla & 21.43 \\
\hline & & Squaliuspamvoticus & 57.14 \\
\hline \multirow[t]{4}{*}{ (7) } & \multirow[t]{4}{*}{103} & Pelasgusthesproticus & 64.08 \\
\hline & & Barbuspeloponnesius & 20.39 \\
\hline & & Telestespleurobipunctatus & 14.56 \\
\hline & & Valencia letourneuxi & 0.97 \\
\hline \multirow[t]{5}{*}{ (8) } & \multirow[t]{5}{*}{34} & Pelasgusthesproticus & 64.71 \\
\hline & & Barbuspeloponnesius & 11.76 \\
\hline & & Telestespleurobipunctatus & 17.65 \\
\hline & & Caspiomyzongraecus & 2.94 \\
\hline & & Anguilla anguilla & 2.94 \\
\hline
\end{tabular}

$V$. letourneuxi was found in slow running stream ditches, flowing into the lake, with dense aquatic vegetation. Therefore, in our investigation we mainly focused on sites with similar conditions, however, we also sampled habitats with higher flow and/or sparse surface vegetation. Out of the eight sampling sites, $V$. letourneuxi was found in four sites (WPwaypoints 1, 2, 3 and channel in the vicinity of WP 7, Fig. 1). The relative abundance of $V$. letourneuxi ranged from $0.97 \%$ to 7.69\% (Tab. 2).

Eleven fish species (total number of fish 616)were found during this survey of the Lake Butrinti area (Tab. 2, Fig. 3).
The species represent 11 genera and seven families (in Cypriniform fish we follow Schönhuth et al., 2018). The list of identified taxa includes: Valencia letourneuxi, Pelasgus thesproticus (Stephanidis, 1939), Telestes pleurobipunctatus (Stephanidis, 1939), Squalius pamvoticus (Stephanidis, 1939), Barbus peloponnesius (Valenciennes, 1842), Anguilla anguilla (Linnaeus, 1758), Alburnus sp., Salaria fluviatilis (Asso, 1801), Pachychilon pictum (Heckel \& Kner 1925), Mugil sp., and Caspiomyzongraecus (Renauld \& Economidis, 2010). Nine species are considered native, while $P$. pictum and Alburnus sp. are considered translocated, as these species were not previously reported in the Ionian drainages (Economou et al., 2007; Barbieri et al., 2015; Bianco and Nordlie 2008; Corral-Lou et al. 2019; Palandačić et al. 2017). Five species are restricted to the Ionian Eco region (Economou et al., 2007; Barbieri et al., 2015), while P. thesproticusis also known from the Vjosa/Aoos river basin in the southeastern Adriatic Ecoregion (Shumka et al., 2018; ecoregions follow Abell et al., $2008)$; this represents a very high degree of endemicity $(66.7 \%$ species being unique to the region).

The most abundant species, in descending order of their relative abundance, were $P$. thesproticus, B. peloponnesius, T. pleurobipunctatus and $S$. pamvoticus, accounting for ca. $90 \%$ of all individuals collected (Tab. 2). The most widespread species (occurrence $>50 \%$ samples) were: $P$. thesproticus, B. peloponnesius, T. pleurobipunctatus, S. pamvoticus, A. anguilla, $V$. letourneuxi and $S$. fluviatilis.

\subsection{Responses to environmental parameters and microhabitat use}

Mean values \pm standard error of percentage vegetation percentage, water flow, conductivity, $\mathrm{pH}$, dissolved oxygen concentration (D.O) and water temperature, as well as information on dominant substrate of the sampling sites are presented in Table 3. Mean values of depth (m) varied from $0.4 \pm 0.25 \mathrm{~m}$ to $2.5 \pm 0 \mathrm{~m}$, while \% vegetation cover varied from $8.6 \pm 2.5$ to $41.5 \pm 11$. All sampling sites were characterised by well oxygenated water (D.O $>8.9 \mathrm{mg} / \mathrm{l})$. Sampling site temperature varied from 13.5 to $18.5^{\circ} \mathrm{C}$. pH values ranged from 7.22 to 7.43 . Conductivity recorded varied between 220 and $3.120 \mu \mathrm{S} \mathrm{cm}^{-1}$ (Tab. 3).

For the seven habitat and physical-chemical variables utilised (\% vegetation cover, D.O, $\mathrm{pH}$, conductivity, flow, depth and temperature, among the various groups of sites with presence or absence of $V$. letourneuxi) we obtained several significant correlations, using correlation matrices, indicating a high degree of co-variation among them. All the physical variables of the water bodies presented significant correlation with D.O., except $\mathrm{pH}$ and conductivity. Analysing all independent variables together, we found significant correlations between flow, depth and channel morphology.

The two axes of the PCA explained the majority (60\%) of the environmental variation encountered in the sampling sites (Fig. 5). Axis one was strongly correlated with channel morphology, vegetation cover and dissolved oxygen.

The tree-plot similarity clusters (Fig. 6) were illustrated in the ordination MDS plot (Fig. 7). The analysis showed that two locations that are typically spring-fed-streams (WP 1 and 2) are reflecting a particular similarity that lies in the following abiotic parameters: \% vegetation cover, D.O, pH, conductivity, 
S. Shumka et al.: Knowl. Manag. Aquat. Ecosyst. 2020, 421, 45

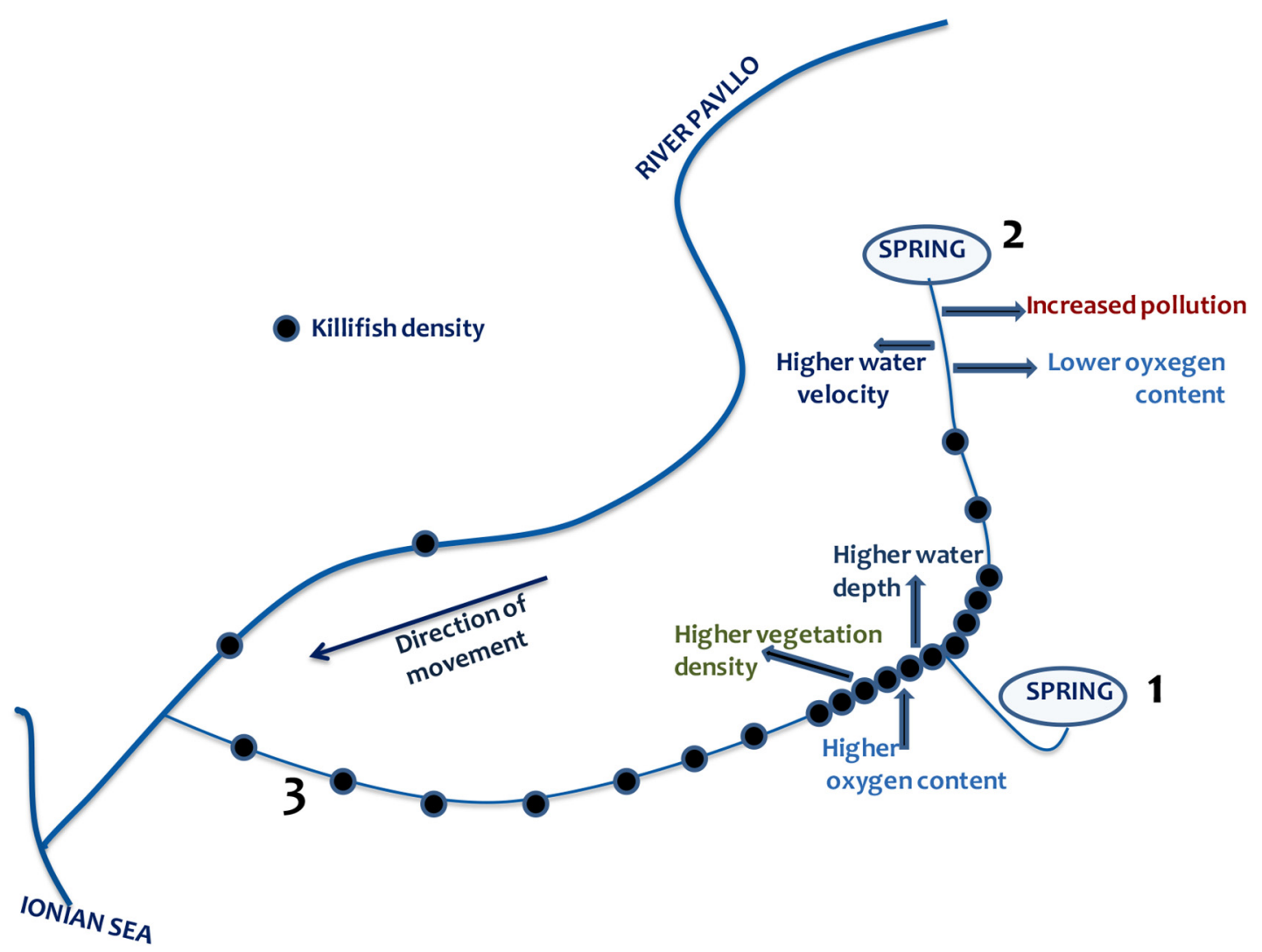

Fig. 2. Relative abundance relation of $V$. letourneuxiat the spring-fed aquatic system of location 1,2 and 3.
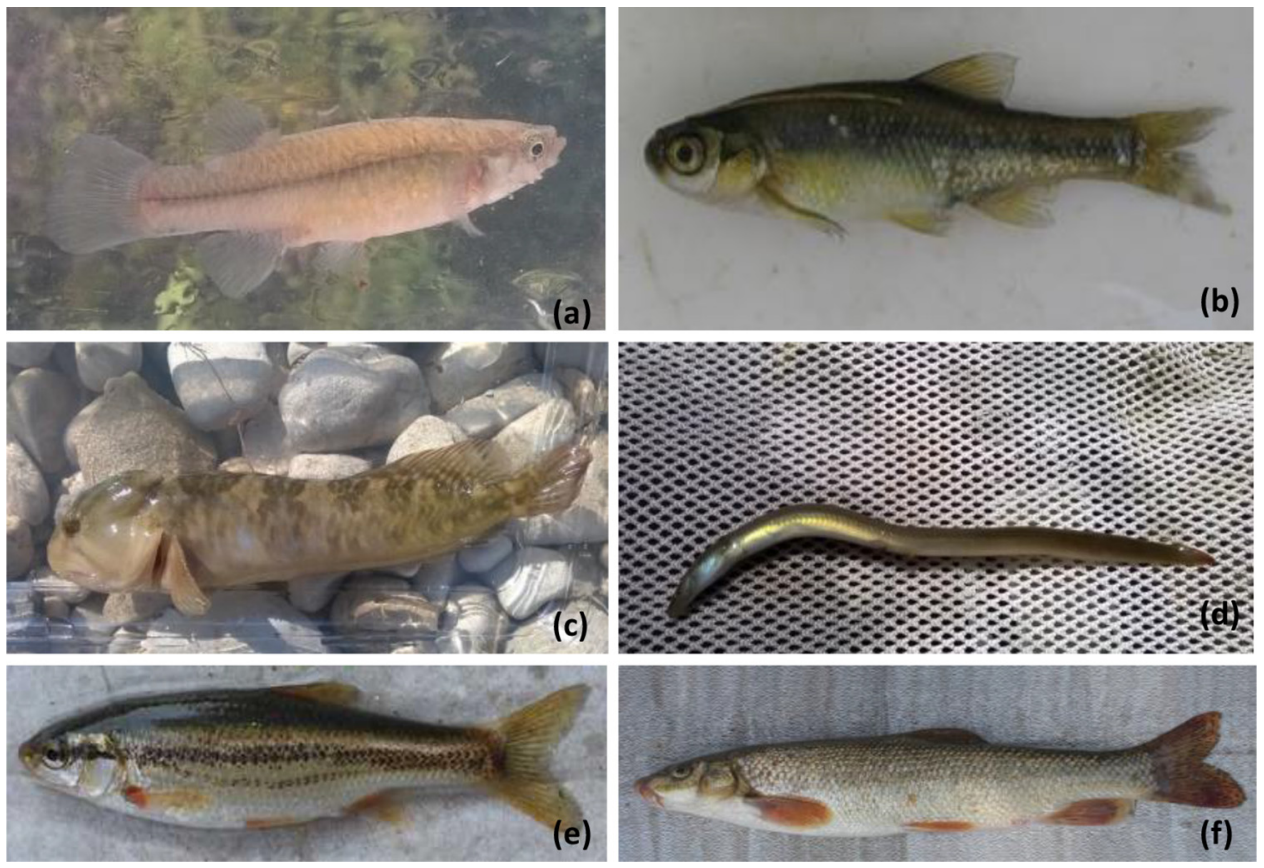

Fig. 3. Fish species: (a) Valencia letourneuxi, (b) Pelasgusthesproticus, (c) Salariafluviatilis, (d) Anguilla anguilla, (e) Telestespleurobipunctatus, (f) Barbuspeloponnesius. 
Table 3. Mean values \pm standard error of the vegetation percentage, water flow, conductivity, $\mathrm{pH}$, dissolved oxygen concentration (D.O) and temperature.

\begin{tabular}{lllllllll}
\hline Site-WP & Conductivity & $\mathrm{pH}$ & D.O. & Temperature & Vegetation & Flow & Depth & Substrate \\
\hline$(1)$ & 786 & 7.42 & 9.5 & 17.8 & $41.5 \pm 11.2$ & $1.1 \pm 0.2$ & $1.5 \pm 0$ & Silt \\
$(2)$ & 792 & 7.40 & 9.4 & 17.2 & $39.5 \pm 7.5$ & $1.2 \pm 0.2$ & $1 \pm 0$ & Silt \\
$(3)$ & 788 & 7.43 & 9.1 & 18.1 & $33.2 \pm 15.5$ & $0.9 \pm 0.2$ & $2.2 \pm 0.32$ & Silt/sand \\
$(4)$ & 439 & 7.33 & 8.9 & 17.5 & $22.5 \pm 16.5$ & $1.5 \pm 0.3$ & $0.4 \pm 0.25$ & Silt/gravel \\
$(5)$ & 355 & 7.22 & 9.2 & 18.1 & $9.5 \pm 5.6$ & $1.6 \pm 0.2$ & $0.8 \pm 0.25$ & Sand/silt/gravel/cobble \\
$(6)$ & 3120 & 7.22 & 9.8 & 13.5 & $40.2 \pm 9.3$ & $1.8 \pm 0.0$ & $2.2 \pm 0.455$ & Gravel/sand \\
$(7)$ & 236 & 7.26 & 9.5 & 17.6 & $32 \pm 5.5$ & $1.1 \pm 0.0$ & $1.5 \pm 0$ & Silt \\
$(8)$ & 220 & 7.22 & 9.7 & 18.5 & $8.6 \pm 2.5$ & $2.1 \pm 0.0$ & & Silt/cobble/boulders \\
\hline
\end{tabular}
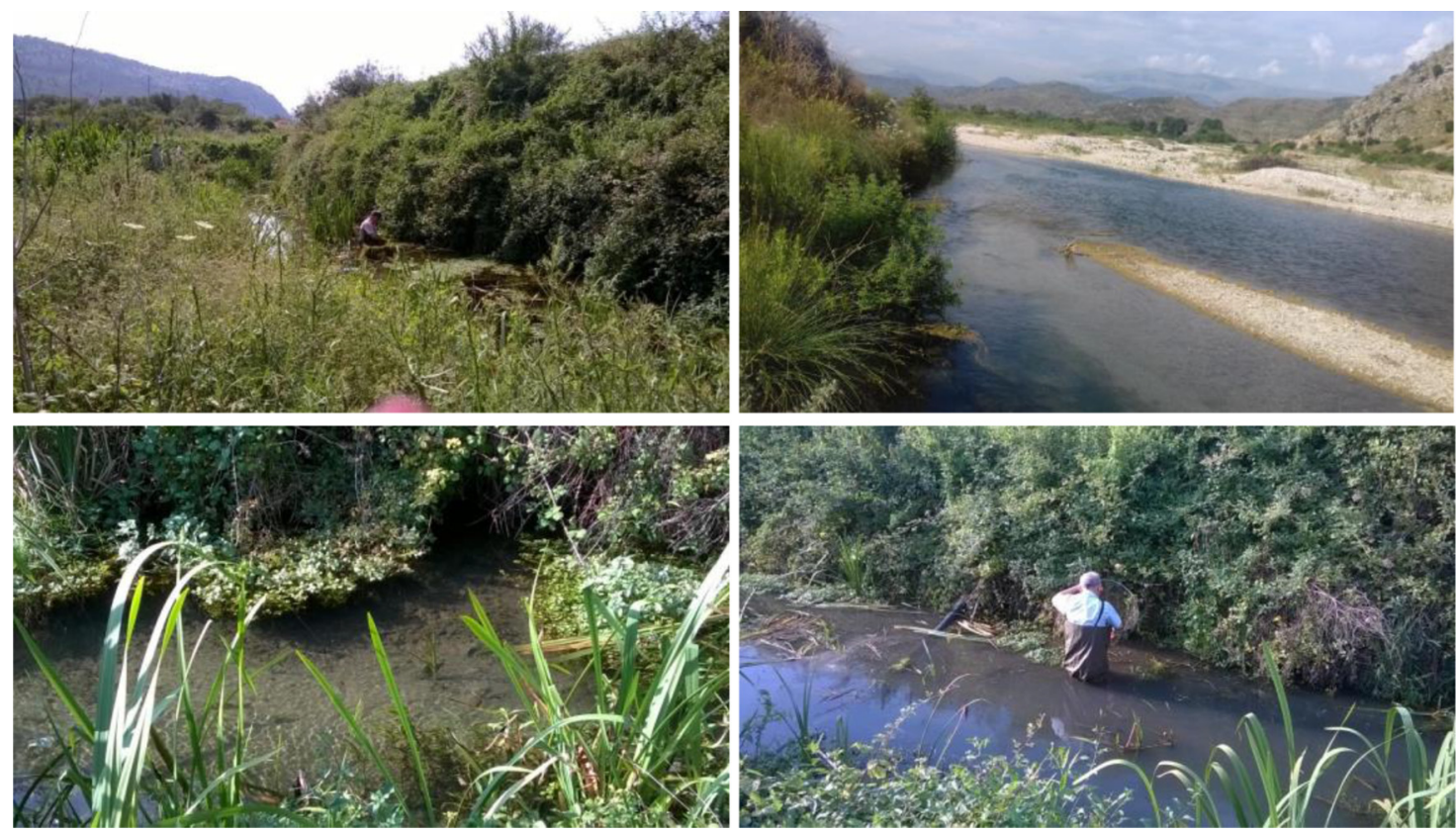

Fig. 4. Habitats surveyed in the Lake Butrinti area.

flow, depth and temperature. Further analysis (DCA) indicated that unimodal models were more suitable than linear models (SD >3; Ter Braak \& Šmilauer 1998).

Valencia letourneuxi presence correlated negatively with water depth and positively with aquatic vegetation cover (Figs. 5 and 6). This conforms to Kalogianni et al. (2010) that indicated a positive correlation with aquatic vegetation and a negative correlation with turbidity. Based on the findings of Das (1985), Barbieri et al. (2000) and Kalogianni et al.(2010), V. letourneuxi appears to exhibit a preference for richly vegetated, well oxygenated and nonturbid sites. Furthermore, low flow conditions enable the development of dense aquatic vegetation that provides shelter and food for the species (Kalogianni et al., 2010). According to Kalogianni et al. (2010), habitat specialisation (rich aquatic vegetation coverage, well-oxygenated and clear water) poses further constraints to the species' distribution and population size. In our survey, we also found an association of the target species with springs and spring-fed streams (Figs. 2 and 8).
MDS ordination shows a progression of grouping from southeastern to eastern locations of Lake Butrinti, with distinctive spring-fed streams. The eight sites sampled in spring and summer maintained similar assemblage structure (Fig. 8). Bipartite network analyses suggest the existence of two preliminary fish assemblage types. The southeastern sampling locations set had the highest species richness and diversity per site (Figs. 7 and 8). Three spring-fed streams species occurred exclusively in the upstream locations, while several species, found exclusively in the most downstream warm sections, respectively.

\subsection{Threats and conservation options}

The knowledge of fish assemblage in general and of particular species may directly help in addressing conservation needs and designing appropriate and targeted conservation measures. Human population presence, land use changes, and socioeconomic development continue to impact aquatic ecosystems and native freshwater fishes. Beside the high 


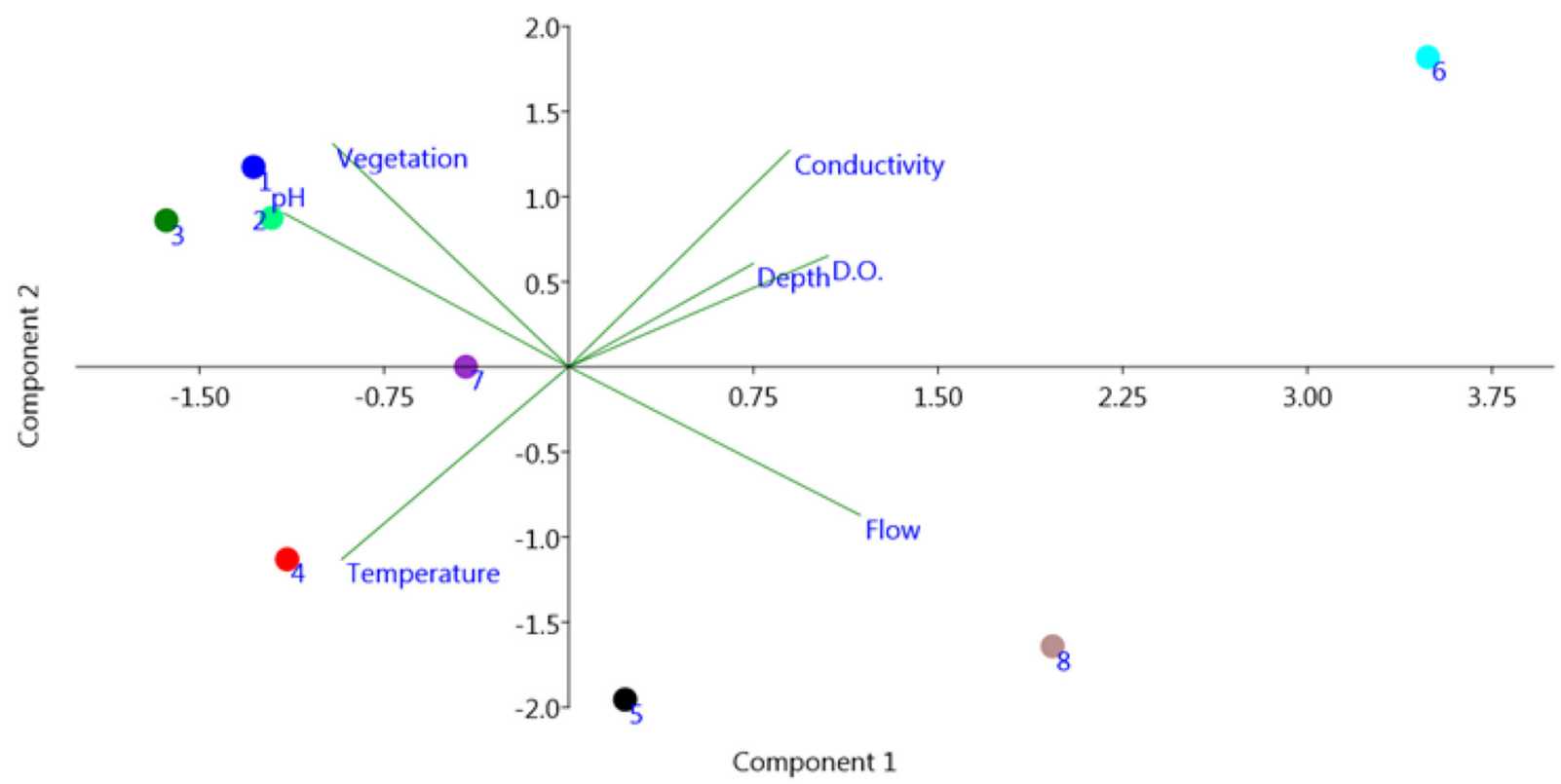

Fig. 5. Ordination of the environmental variables at the aquatic systems sampled for $V$. letourneuxi presence.

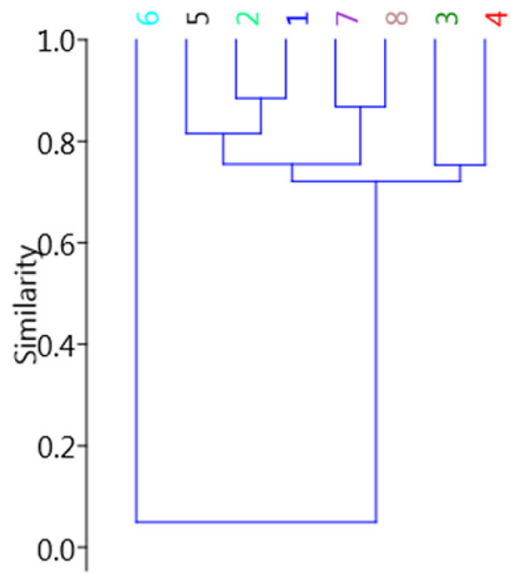

Fig. 6. Tree plot similarity in terms of $V$. letourneuxi presence (numbers denote sampling locations).

diversity in many freshwater fish communities, there are no developments with regards to species and watershed approaches to the science, planning, and delivery of freshwater fish conservation at the local scale in many regions. Fish are sensitive to increased sediment load, dam construction and eutrophication processes (Schmutz et al., 2000; Richter et al., 2003; Angermeier et al., 2004). The southernmost Albanian Ionian region of freshwaters in general and River Pavllo drainage in particular are facing similar pressures that affect fish assemblages, but due to the lack of historical data with regard to fish assemblages, there are difficulties in discussing conditions that are influenced by anthropogenic changes. Below, we underline the specific conservation issues of conservation interest related to our study:

- Water pollution, both due to wastewater discharges and solid waste disposal represents a main problem for the
$V$. letourneuxi habitats, i.e. the tributaries of the River Pavllo. Sewage waters are commonly discharged as untreated water into the streams, since in the wider area there is only one sewage treatment plant in operation, serving exclusively the city of Saranda. Along with sewage water, there are also discharges from the small-scale food industry units (dairy) and restaurants. The local effect of these discharges was evident, once the fish assemblage at location 1 and 2 with higher presence of $V$. Letourneuxi was analysed at the longitudinal axis from downstream to upstream. At these locations (WP 1 and 2; Fig. 2) heavy benthic siltation (caused by the intensive agriculture and land use changes) is probably associated with anthropogenic impacts and may also negatively influence fish (Rovira and Batalla 2006; Magoulick, 2000; Aguiar et al. 2002; Rovira and Batalla 2006).

- Water abstraction. We believe that within current circumstances, particularly during the summer low fish abundances (catch per unit effort) are expected in a site affected by water abstraction (this includes the River Pavllo and all tributaries that are heavily used for irrigation for agriculture, particularly fruticulture). Reduced flow is known to reduce survival and reproduction and to promote emigration of stream fishes (Matthews et al., 2003; Keaton et al., 2005; Davey et al., 2007). Benejam et al. (2010) detected four fish metrics (catch per unit effort, number of benthic species, number of intolerant species and proportion of intolerant individuals) that separated sites impacted by water abstraction and un-impacted sites with significant temporal trends in response to abstraction. In our case due to study time limitations and lack of historical data, this approach should be regarded as preliminary and needing further data and validation.

- Limited information on taxonomy, population genetic diversity and life history of the riverine fishes in the Balkans, particularly in Albania. In such situation, lack of 


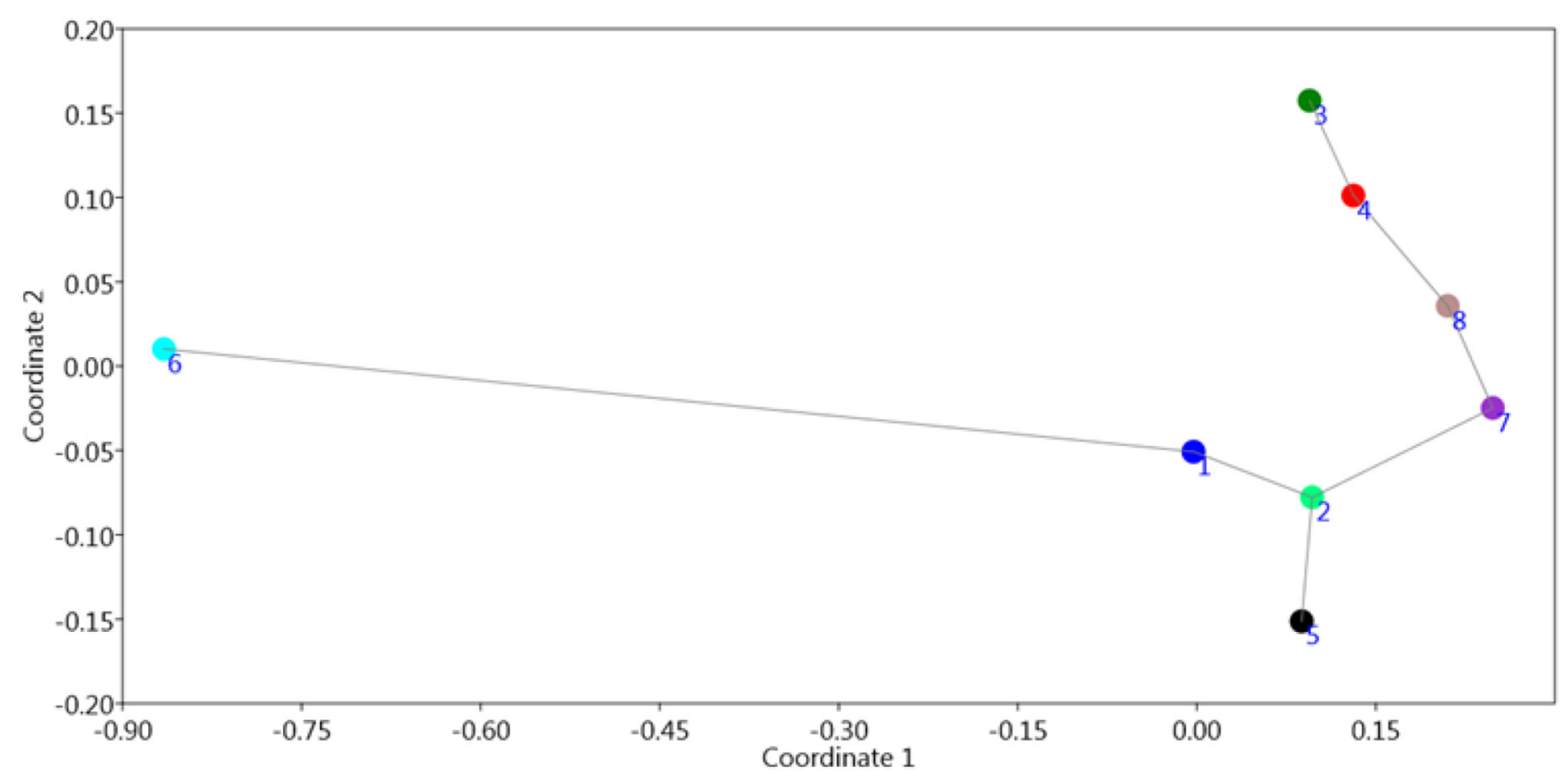

Fig. 7. Multi Dimensional Scaling (MDS) ordination of the Burinti area samples based on fish density. Site 6 on the right half of ordination is in the brackish water conditions in the entering location to Lake Buffi.

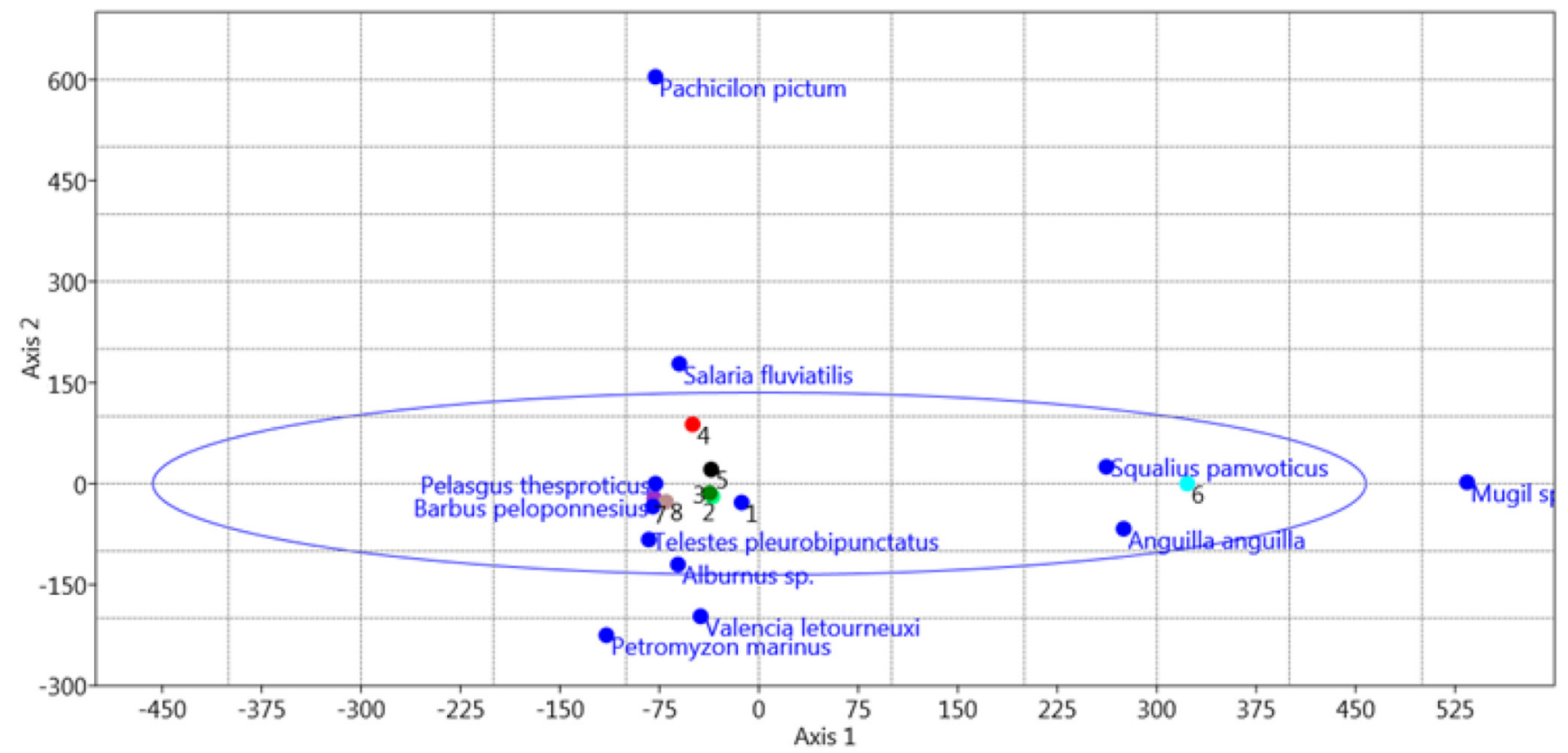

Fig. 8. Partial CCA analyses, species related to sampling locations (indicated with colored numbers).

taxonomic clarity hinders development of effective conservation strategies (Hogan, 2011; Perdices et al. 1996; Planelles 1996; Planelles and Reyna 1996). Implications become clear once the issue of the presence of genus Pelasgus, Barbus and Squalius in the area of concern is discussed. Furthermore, referring to the current situation in Albania and neighboring countries, there is still uncertainty and knowledge gaps (Šanda et al., 2008; Weiss et al., 2018; Vavalidis et al., 2019). The basic information on life history and reproductive biology including age-at-maturation and fecundity are often not known for imperiled species. In contemporary fisheries management, such information is the basis for modeling and selection of various management actions (Cooke, 2012).

- Limited public awareness and effectiveness of measures for the conservation and management of river fish populations. Beside the conservation status and attention given to the cultural importance of the Butrinti National Park for the younger generations, it seems that the natural 
assets and biodiversity of the wider area has not been appreciated. Lack of effectiveness and capacity of the protected area administration, and economic priority given to agriculture and tourism development hinders the conservation of threatened fish species. Following Cooke et al. (2012); Richter et al. (2003), having in mind the particularity of the case, it is clear that the management and conservation status of many freshwater fish species in the transboundary rivers (as River Pavllo) might be improved also through international cooperative efforts.

Finally, the sites in both the southeastern and eastern part of the Lake Butrinti region represent outstanding examples of natural water flow habitats in the RiverPavllo catchment and they should be studied and considered sites for conservation within the protected areas. For a comprehensive conservation plan, including an assessment of possible climate change effects on the biota, fish surveys and monitoring using a standardised methodology should be established on the RiverPavllo and all its tributaries.

Acknowledgements. Financial support for this survey was provided by the CEPF Mediterranean Basin Biodiversity Hotspot programme through supported project: "A multidisciplinary conservation initiative to save Butrinti's (and northern Greece) Critically Endangered killifish - Valencia letourneuxi from imminent extinction" 2019-2020; the field work was carried out with permit of the Ministry of Tourism and Environment, National Agency of Protected Areas, Tirana, Albania, nr. 4896.

\section{References}

Aguiar FC, Ferreira MT, Pinto P. 2002. Relative influence of environmental variables on macroinvertebrate assemblages from an Iberian basin. J N Am Benthol Soc 21: 43-53.

Abell R, Thieme ML, Revenga C, Bryer M, Kottelat M, Bogutskaya N, Coad B, Mandrak N, Contreras-Balderas S, Bussing W, Stiassny MLJ, Skelton P, Allen GR, Unmack P, Naseka A, Ng R, Sindorf N, Robertson J, Armijo E, Higgins JV, Heibel TJ, Wikramanayake E, Olson D, Lopez HL, Reis RE, Lundberg JG, Sabaj-Pırez MH, Petry P. 2008. Freshwater ecoregions of the world: A new map of biogeographic units for freshwater biodiversity conservation. BioScience 58: 403-414.

Angermeier P, Winston M. 2003. Assessing conservation value of stream communities: a comparison of approaches based on centres of density and species richness. Freshwater Biology 37: 699-710.

Angermeier PL, Davideanu G. 2004. Using fish communities to assess streams in Romania: initialdevelopment of an index of biotic integrity. Hydrobiologia 511: 65-78.

Barbieri R, Daoulas C, Psarras T, Stoumboudi MT, Economou AN. 2000. The biology and ecology of Valencia letourneuxiSauvage, 1880 (Valenciidae) - Prospects for conservation. Medit Mar Sci 1: 75-90.

Barbieri R, Stoumboudi MT, Economou AN. 2002. Threatened fishes of the world: Valencia letourneuxi Sauvage, 1880 (Valenciidae). Environ Biol Fish 65: 46-59.

Barbieri R, Zogaris S, Kalogianni E, Stoumboudi MT, Chatzinikolaou Y, Giakoumi S, Vardakas L. 2015. Freshwater fishes and lampreys of Greece: An annotated checklist, 203 p.
Bianco PG, Miller RR. 1989. First record of Valencia letourneuxi (Sauvage, 1880) in Peloponnese (Greece) and remarks on the mediterranean family Valenciidae (Cyprinodontiformes). Cybium 13: $385-387$.

Bianco PG, Nordlie F. 2008. The salinity tolerance of Pseudophoxinus stymphalicus (Cyprinidae) and Valencia letourneuxi (Valenciidae) from western Greece suggests a revision of the ecological categories of freshwater fishes. Ital J Zool 75: 285-293.

Benejam L, Angermeier P, Mune A, Garchia-Berthou E. 2010. Assessing effects of water abstraction on fish assemblages in Mediterranean streams. Freshw Biol 55: 628-642.

Crivelli AJ. 2006. Valencia letourneuxi. The IUCN Red List of Threatened Species 2006: Version 2012. 2. www.iucnredlist.org. Downloaded on 18 August 2019.

Crivelli AJ, Maitland PS. 1995. Introduction. Biological Conservation special issue: Endemic freshwater fishes of the Northern Mediterranean region. Biol Conserv 72: 121-132.

Cooke A, Paukert C, Hogan Z. 2012. Endangered river fish: factors hindering conservation and restoration. Endangered Species Res 17: 179-191.

Corral-Lou A, Perea S, Aparicio E, Doadrio I. 2019. Phylogeography and species delineation of the genus Phoxinus Rafinesque, 1820 (Actinopterygii: Leuciscidae) in the Iberian Peninsula. J Zool Syst Evol Res 57: 926-941.

Daoulas C. 2003. New records of Economidichthyspygmaeus (Holly, 1929) (Gobiidae) and Valencia letourneuxi (Sauvage, 1880) (Valenciidae) in Western Greece, pp. 109-112. Proceedings of the 11th Panhellenic Ichthyological Congress, Preveza, Greece.

Darwall W, Carrizo S, Numa C, Barrios V, Freyhof J, Smith K. 2014. Freshwater Key Biodiversity Areas in the Mediterranean Basin Hotspot: Informing species conservation and development planning in freshwater ecosystems. Cambridge, UK and Malaga, Spain: IUCN, 86p.

Das J. 1985. On the biology and ecology of Valencia letourneuxi (Sauvage, 1880) (Teleostei, Cyprinodontiformes) in the Aheron Kokitos - River - Drainage in northwestern Greece. Bonn Zool Beitr 36: 163-176.

Davey AJ, Kelly DJ. 2007 Fish community responses to drying disturbances in an intermittent stream: a landscape perspective. Freshw Biol 52: 1719-1733.

Dill WA. 1993. Inland fisheries of Europe. EIFAC Technical Paper, No. 52 Suppl. Rome, FAO, 170 p.

Economou AN, Giakoumi S, Vardakas L, Barbieri R, Stoumboudi M, Zogaris S. 2007. The freshwater ichthyofauna of Greece - an update based on a hydrographic basin survey. Medit Mar Sci 8: 91-166

Freyhof J, Kärst H, Geiger M. 2014. Valencia robertae, a new killifish from southern Greece (Cyprinodontiformes: Valenciidae). Ichthyol Explor Freshw 24: 289-298

Geiger MF, Herder F, Monaghan MT, Almada V, Barbieri M, Bariche M, Berrebi P, Bohlen J, Casal-Lopez M, Delmastro GB, Denys GPJ, Dettai A, Doadrio I, Kalogianni E, Kärst H, Kottelat M, Kovačić M, Laporte M, Lorenzoni M, Marčić Z, Özulug M, Perdices A, Perea S, Persat H, Porcelotti S, Puzzi C, Robalo J, Šanda R, Schneider M, Šlechtová V, Stoumboudi M, Walter S, Freyhof J. 2014. Spatial heterogeneity in the Mediterranean biodiversity hotspot affects barcoding accuracy of its freshwater fishes. Mol Ecol Resour 14: 1210-1221.

Hogan Z. 2011. Ecology and conservation of large-bodied freshwater catfish: a global perspective. In: Michaletz PH, Travnichek VH (eds) Conservation, ecology, and management of catfish: the second international symposium. American Fisheries Society Symposium 77. American Fisheries Society, Bethesda, MD, p 39-53. 
Kalogianni E, Giakoumi S, Zogaris S, Chatzinikolaou Y, Zimmerman B, Economou AN. 2010. Current distribution and ecology of the critically endangered Valencia letourneuxi in Greece. Biologia 65: 128-139.

Kalogianni E, Koutsikos N, Vardakas L, Giakoumi S, Chatzinikolaou Y, Oikonomou A. 2019. Impacts of the alien mosquitofish on the abundance and condition of two Mediterranean native fish. Mediterranean Marine Sci 20: 727-735.

Keaton M, Haney D, Andersen CB. 2005 Impact of drought upon fish assemblage structure in two South Carolina Piedmont streams. Hydrobiologia 545: 209-223.

Kottelat M, Freyhof J. 2007. Handbook of European Freshwater Fishes. Kottelat, Cornol, Switzerland and Freyhof, Berlin, Germany, $646 \mathrm{p}$.

Legakis A, Maragou P. 2009. The red book of endangered animals of Greece. Hellenic Zoological Society, Athens, Greece.

Magoulick DD. 2000. Spatial and temporal variation in fish assemblages of drying stream pools: the role of abiotic and biotic factors. Aquatic Ecol 34: 29-41.

Matthews WJ, Marsh-Matthews E. 2003. Effects of drought on fish across axes of space, time and ecological complexity. Freshw Biol 48: $1232-1253$.

Marková S, Šanda R, Crivelli A, Shumka S, Wilson IF, Vukić J, Berrebi P, Kotlík P. 2010. Nuclear and mitochondrial DNA sequence data reveal the evolutionary history of Barbus (Cyprinidae) in the ancien lake systems of the Balkans. Mol Phylogenet Evol 55: 488-500.

Myers GS. 1928. Two new genera of fishes. Copeia 1928: 7-8.

Myers N, Mittermeier RA, Mittermeier CG, da Fonseca GAB, Kent J. 2000. Biodiversity hotspots for conservation priorities. Nature 403: $853-858$.

Oliva O. 1961. Bemerkungen"Uber einige Fischarten aus Albanien. Acta Soc Zool Bohemoslov 25: 39-54.

Oliva O. 1965. Zum Vorkommen von Valencia hispanica (Val.1846) auf Korfu. Bonn Zool Beitr 16: 308-315.

Oliva-Paterna, Francisco J, Nuno C, Torralva M. 2009. Threatened fishes of the world: Valencia hispanica (Valenciennes, 1846) (Valenciidae). Environ Biol Fishes 85: 275-276.

Palandačić A, Naseka A, Ramler D, Ahnelt H. 2017. Contrasting morphology with molecular data: an approach to revision of species complexes based on the example of European Phoxinus (Cyprinidae). BMC Evol Biol 17: 184-198.

Parenti LR. 1981. A phylogenetic and biogeographic analysis of cyprinodonti form fishes (Teleostei, Atherinomorpha). Bull Am Museum Natural History 168: 335-557.

Perdices A, Machordom A. Doadrio I. 1996. Allozymic variation and relationships of the endangered cyprinodontid genus Valencia and its implications for conservation. J Fish Biol 49: 1112-1127.

Planelles M. 1996. The last populations of samaruc Valencia hispanica (Valenciennes 1846): Distribution, status and recovery efforts. Publ Espec Inst Esp Oceanogr 21: 263-268.

Planelles M, Reyna S. 1996. Conservation of samaruc, Valencia hispanica (Valenciennes, 1846), (Pisces: Cyprinodontidae), an endemic and endangered species, in the community of Valencia (east Spain), pp. 329-335. In: Kirchhofer A., Hefti D. (eds), Conservation of Endangered Freshwater Fish in Europe, BirkhauserVerlag, Basel.
Richter BD, Mathews R, Wigington R. 2003. Ecologically sustainable water management: managing river flows for ecological integrity. Ecol Appl 13: 206-224.

Rovira A, Batalla RJ. 2006. Temporal distribution of suspended sediment transport in a Mediterranean basin: the lower Tordera (NE Spain). Geomorphology 79: 58-71.

Šanda R, Vukić J, Choleva L, Kř́žžek J, Šedivá A, Shumka S, Wilson IF. 2008. Distribution of loach fishes (Cobitidae, Nemacheilidae) in Albania, with genetic analysis of populations of Cobitisohridana. Folia Zool 57: 42-50

Schönhuth S, Vukić J, Šanda R, Yang L, Mayden RL. 2018. Phylogenetic relationships and classification of the Holarctic family Leuciscidae (Cypriniformes: Cyprinoidei). Mol Phyl Evol 127: 781-799.

Schmutz S, Kaufmann M, Vogel B, Jungwirth M, Muhar S. 2000. A multi-level concept for fish-based, river-type-specific assessment of ecological integrity. In: Jungwirth M, Muhar S, Schmutz S. (eds.), Assessing the Ecological Integrity of Running Waters, Kluwer Academic Publishers, Dordrecht, 279-289.

Seegers L. 1980. Und doch: Valencia auf Corfu! DKG-Journal (Köln) 12: $152-154$.

Shumka S, Meulenbroek P, Schiemer F, Šanda R. 2018. Fishes of River Vjosa-an annotated checklist. Acta Zoo Bot Austria 155: $163-176$

Shumka S. 2019. Natura 2000 potential sites in Albaniaa contribution of fish species of community interest. Proceedings Book of the 3rd International Symposium for Environmental Science and Engineering Research, 25-27 May 2019, Konya, Turkey. pp. 21-30.

Sutela T, Vehanen T, Jounela P. 2010. Response of fish assemblages to water quality in boreal rivers. Hydrobiologia 641: 1-10

Ter Braak CJF, Šmilauer P. 1998. CANOCO Reference Manual and User's Guide to Canoco for Windows: Software for Canonical Community Ordination (version 4). Centre for Biometry, Wageningen, $351 \mathrm{pp}$.

Vavalidis T, Zogaris S, Economou AN, Kallimanis AS, Bobori DC. 2019. Changes in Fish Taxonomy Affect Freshwater Biogeographical Regionalisations: Insights from Greece. Water 11: 1743-1761.

Vilwock W, Scholl A, Labhart P. 1982. Die gattung Valencia ein Beitrag zur Verbreitung und Taxonomie. Mitt Hamb Zool Mus Inst 79: 273-280.

Weiss S, Apostolou A, Đug S, Marčić Z, Mušović M, Oikonomou A, Shumka S, Škrijelj R, Simonović P, Vesnić A, Zabric D. 2018. Endangered Fish Species in Balkan Rivers: their distributions and threats from hydropower development. Riverwatch\&EuroNatur, $162 \mathrm{p}$.

Woeltjes T. 1982. Valencia hispanica letourneuxi van Corfu enGriekenland. Killi-Nieuws 11: 107-115.

Woeltjes T. 1988. Valencia letourneuxi and Aphaniusfasciatus from Corfu and Greece. JA KA 21: 26-38.

Zupančič P, Marić D, Naseka AM, Bogutskaya NG. 2010. Squaliusplatyceps, a new species of fish (Actinopterygii: Cyprinidae) from the Skadar Lake basin. Zoosystematica Rossica 19: $154-167$.

Cite this article as: Shumka S, Kalogianni E, Šanda R, Vukić J, Shumka L, Zimmerman B. 2020. Ecological particularities of the critically endangered killifish Valencia letourneuxi and its spring-fed habitats: a long-lost endemic species of south Albania. Knowl. Manag. Aquat. Ecosyst., 421, 45. 